\title{
Effect of Formative Classroom Assessment on Students' Academic Achievement in Junior Secondary School Basic Science in Egor Local Government Area of Edo State, Nigeria
}

\author{
MATILDA, U. ORHERUATA (P.hD) ${ }^{*}$ HELEN, A. OYAKHIROME (Ph.D) \\ University of Benin, Edo State, Nigeria
}

\begin{abstract}
The research investigated the effect of formative classroom assessment on students' achievement in junior secondary school Basic science in Egor Local Government Area of Edo State. The study adopted a pre-test, posttest experimental design. The population of the study comprised all the public Junior Secondary School two (JSS II) students out of which 80 students were purposively sampled and used for the study. Basic Science Achievement Test (BSAT) was used for the pre-test and post-test. The instrument was content validated by Basic science teachers who are experts in the subject. The reliability of the BSAT was determined by the test-retest method yielding a reliability co-efficient of 0.70 . Data collected were analysed using paired sample t-test and independent sample t-test at 0.05 level of significant. The Findings revealed that formative classroom assessment had effect on the students' academic achievement in favour of the experimental group; formative classroom assessment was also found to improve the students' academic achievement as observed in the difference between pre-test and post-test in favour of the post-test; and no significant difference in the scores of male and female exposed to the formative classroom assessment. It was recommended that teaching and learning at the junior secondary school should be improved by regular formative classroom assessment with adequate feedback and remediation for learners to improve their academic achievement.
\end{abstract}

Keywords: Assessment, Formative assessment, Classroom, Academic achievement

DOI: $10.7176 / \mathrm{JEP} / 10-15-22$

Publication date:May $31^{\text {st }} 2019$

\section{Introduction}

The classroom is basically a training environment where teaching and learning process take place. It is a center for a dynamic system of interactions where the teacher is to effectively instruct the learners in a manner that will bring about changes in the behavior of learners and determine the students' level of achievement in the course of study. Within the classroom setting, the teacher attempts to gain knowledge of competencies his/her students brought to the classroom and what they have acquired as a result of instructions. This is achieved through classroom assessment. Assessment is the collection of information for making decisions about the students, curricula and programmes and educational policy (Nitko \& Brookhart, 2007). Assessment of students' progress and achievement is a very vital component of any educational system. The assessment of students' achievement is changing largely as students face a world that demands new knowledge, abilities and skills. Helping the students develop these skills require changes in the assessment at the school and classroom levels as well as new approaches to the largescale and high-stake assessment (Suliman, 1999). Assessment should be a tool of teaching and learning and not to be interpreted as the objective of student's learning experience. It should be viewed as a series of well-planned and systematic measurement that will enable the teacher to make an authentic and valid decision about a learner. As students' population in secondary schools in Nigeria increases, classroom assessments assume more central role in enhancing students learning in order to meet distinct academic standards.

Classroom assessment is an attempt geared towards assisting the teacher to update his judgment of the learners, as through it the teacher can be very current as regards the status of his learners. Specifically, classroom assessment involves a wide range of processes such as paper-and-pencil test, performance and project rating, observations, interviews by the which the teacher collect information about student learning. The reasons for classroom assessment are to provide feedback to students; to make informed decisions about students; to establish and maintain a supportive classroom learning atmosphere amongst others and the focus is on the level of Knowledge, skills or understanding of individual students in the classroom and the diagnosis of problems they may be encountering, with the view to make decisions (Gronlund, $2006 \&$ Joshua, 2013). Assessment in the classroom typically involve placement, formative and summative assessment. Placement (Pre- assessment) is done to determine if students have enough prior knowledge to begin new instruction. Formative assessment is that done during when instruction is ongoing in the classroom. The purpose is to identify specific areas of learning difficulties and to make adequate adjustment to promote learning. While summative assessment is done at the end or after instruction or programme to ascertain the level the students' achievement in the overall objectives of the programme.

Within the classroom, every teacher's goal is to seek student's growing competence and success in learning. 
When teachers begin to aim at assessing students in the classroom to improve learning and achievement far more than collecting information to assign grades or certifying mastery, therefore, perhaps of greatest importance is formative assessment. According to McManus (2008) formative assessment is a process used by teachers and students during instruction that provides feedback to adjust ongoing teaching and learning to improve students' achievement of intended instructional outcomes. Ojugo (2013) stated that formative assessment is useful to both the students as it helps to diagnose students' learning difficulties and the prescription of alternative remedial measure all towards improvement in the academic achievement in the subject concerned, and to the teacher as means of locating the specific difficulties that students are experiencing within the contents of the subject and forecast the appropriate teaching strategies to help the students understand the difficulties in the contents in order to improve their academic achievements in the subject. Ugodulunwa and Uzoamaka (2015) opined that the key requirements for successful formative assessment include the use of quality assessment tools and the subsequence use of the information derived from these assessments to improve teaching and learning instructions.

Formative assessment is commonly referred to as assessment for learning. Assessment Reform Group (ARD, 2002) explained assessment for learning as any assessment for which the first priority in its design and practice is to serve the purpose of promoting pupils' learning. It differs from assessment designed primarily to serve the purpose of accountability, or for ranking or of certifying competence. William, Lee, Harrison, and Black (2014) argued that assessment for learning occurs when assessment is used to enhance student achievement. Assessment for learning is one in which assessment information is to be used by the teacher and learners to identify areas of difficulty and then execute on-target instruction to assist the learners to adequately fix the issue that is of concern. It requires careful design on the part of teachers so that they use the resulting information to determine not only what students know, but also to gain insights into how, when, and whether students apply what they know. Teachers can also use this information to streamline and target instruction and resources, and to provide feedback to students to help them advance their learning (Afemikhe, 2018). Classroom formative assessments provides immediate feedback to both the teacher and the students regarding the learning process. Formative feedback illustrates the gap between what the student currently knows and understands and what the teacher's expectations are from this knowledge and understanding.

Science has become an indispensable tool that no nation wishing to progress in the socio economic sphere will afford to relegate its teaching and learning to the background. The National Policy on Education (FRN, 2008) recognizes secondary education in Nigeria as a key to provide trained manpower in the sciences, technology and commerce at sub- professional grades. To achieve this stated goal, secondary education runs for six years duration, given in two stages- a junior secondary school stage and a senior secondary school stage. Within the context of science education at junior secondary school stage, Basic Science formally known as Integrated Science has been prescribed as a core school subject that will give the students the basic scientific information that will prepare the student for the study of the core science subjects (physic, chemistry, biology) at the senior secondary school stage. The Basic Science and Technology Curriculum (BSTC, 2012 is expected to enable the learners develop interest, acquire knowledge and skills in science and technology. This shows that a sound knowledge of Basic Science is prerequisite for a student to be able to study single science subjects at the senior secondary school and the higher institution levels successfully. It therefore becomes necessary that the teaching of Basic Science requires appropriate teaching strategies that will help the learners to understand the subject content difficulties in order to achieve success. For the teachers to give the students the background knowledge which they need in enhancing learning and achievement in Basic Science, formative classroom assessment becomes very important.

Mawak and Ugodulunwa (2012) in their study revealed a significant effect of formative feedback on SSII students' achievement in the experimental group than the control group. Ajogbeje (2012) in his study on effect of formative testing with feedback on students' achievement in junior secondary school mathematics in Ondo State reported a significant effect of treatment on students' achievement in mathematics. Ali and Igbal (2013) determined the effect of formative assessment on students' achievement in science at grade level eight. Statistical analysis of the students' means achievement scores on a post-test showed that the Overall performance of the experimental group was significantly better than that of the control group. The boys and the girls of the experimental group performed higher than those of the control group. The high and the low ability students of the experimental group outperformed the students of the respective abilities in the control group, but no significant difference was found between the medium ability students of both the groups.

Similarly, Olagunju (2015) reported that formative assessment has a strong significant difference in the mean achievement score of Mathematics students that are exposed to it; no significant difference in the mean achievement scores of student who are not expose to formative assessment and no gender difference in the achievement scores of Mathematics students that are exposed to formative assessment. He concluded that when formative assessment are used for diagnostic purposes, it improves the academic performance of the students on the subject and also enable them to understand the contents of the subject. Also formative test serve as a basis for finding out the sources of difficulties on the contents of the subject. In this way, the teacher is able to give necessary remediation and correctives measure to improve the understanding of students on the contents of the subject in 
order to improve their academic achievements in the subject concerned. Smith (2008) reported that frequent formative assessments accurately predict achievement on measures of Adequate Yearly Progress (AYP) indicators in math competency tests in the Gainesville School District in Georgia.

Existing research studies reviewed has established the connection of formative assessment to academic students' academic achievement and has consistently demonstrated that formative assessment enhances students' academic performance and academic success. However, this study is an attempt to find out if similar results would be found in Basic Science. Therefore, this study investigates the effect of formative classroom assessment on the achievement in junior secondary school Basic science in Edo State.

\section{Objective of the Study}

To achieve the objective of the study, the following hypotheses were formulated and tested in the course of the study:

- There is no significant difference in the post -test scores in Basic Science of junior secondary school students exposed to formative assessment and those in the control group.

- There is no significant difference in the pre-test and post -test scores in Basic Science of junior secondary school students exposed to formative assessment.

- There is no significant difference between male and female in Basic Science scores of junior secondary school students exposed to formative assessment.

\section{Method}

The research design used for this study was the pretest- posttest experimental design. The population of the study comprised all the Junior Secondary School two (JSS II) students in Egor Local Government Area of Edo State. Two public schools were randomly selected from the 11 schools in the study area. In each of the two schools selected, the researcher used the purposive sampling technique in selecting 80 students who scored less than fifty marks $(50 \%)$ in the second term examination starting from the lowest score. One school was used as the experimental group and the other as control group representing 40 students each out of the sampled students. The Basic Science Achievement Test (BSAT) of twenty - five multiple choice items from selected topics were used for the pre-test, post-test. The instrument was content validated by agricultural science teachers who are experts in the subject. In order to determine reliability of the BSAT test, the test items were administered twice with two weeks interval on twenty students from the target population who did not participate in the study, thus, yielding a test-retest reliability co-efficient of 0.70 .

\subsection{Treatment Procedure}

The experimental and the control groups were pre- tested with the BSAT at the beginning of the term. Students in the experimental group received expository class teaching followed by questioning formative assessment strategy during the course of instruction in each selected topic. The strategy involved the open-ended questions of the dialogic type. This was done by asking thought provoking questions about the learning task and providing sufficient wait time for the students to generate response for feedback and remediation. While the control group received only the expository classroom teaching. The training sessions of the groups lasted for a period of six weeks where each session lasted 35 minutes, twice a week. At the end of the training sessions, the same BSAT was re-administered to both groups to determine the effect of formative assessment strategy on the academic achievement of the experimental group. The data collected were analysed using paired sample t-test and independent sample t-test at 0.05 level of significant.

\section{Results}

Table 1: t-test Statistics of Post- test scores of students' in the Experimental and Control group

\begin{tabular}{|c|c|c|c|c|c|c|}
\hline & $\mathrm{N}$ & Mean & S D & DF & t.cal & $\mathrm{p}(\mathrm{sig})$ \\
\hline Experimental & 40 & 68.43 & 8.25 & 79 & 5.63 & .000 \\
\hline Control & 40 & 43.64 & 5.34 & & & \\
\hline
\end{tabular}

Sig at $\mathrm{P}<0.005$

Table 1 shows that mean score of the experimental group in the post-test is 68.43 while the mean score of the control group in the post- test is 43.64 with a calculated t value of 5.63 and significant $p<0.000$. Therefore, the Null hypothesis is rejected. This implies that significant difference exists in the post-test scores of students' exposed to formative assessment strategy and control group. The significant difference is in favour of the experimental group. 
Table 2: Paired t-test statistics of Pre-test and Post- test scores of students in the Experimental group

\begin{tabular}{|c|r|r|r|r|r|c|}
\hline & $\mathrm{N}$ & \multicolumn{1}{|c|}{ Mean } & S D & DF & t.cal & $\mathrm{p}(\mathrm{sig})$ \\
\hline Pre-test & 40 & 57.64 & 6.34 & 79 & 4.65 & .002 \\
\hline Post-test & 40 & 66.80 & 7.58 & & & \\
\hline
\end{tabular}

Sig at $\mathrm{P}<0.005$

Table 2 above show that mean score of the experimental students in the pre-test is 57.64 while the mean score in the post test is 66.80 with a calculated $t$ value of 4.65 and significant $p<0.002$. Therefore the null hypothesis is rejected. This implies that the significant difference is in favour of the post- test scores.

Table 3: t-test statistics of Post- test scores of Male and Female students' in the Experimental group

\begin{tabular}{|c|c|c|c|c|c|c|}
\hline & $\mathrm{N}$ & \multicolumn{1}{c|}{ Mean } & S D & DF & t.cal & $\mathrm{p}(\mathrm{sig})$ \\
\hline Male & 20 & 61.78 & 13.43 & 39 & 1.46 & .891 \\
\hline Female & 20 & 58.90 & 7.34 & & & \\
\hline
\end{tabular}

Sig at $\mathrm{P}<0.005$

Table 3 shows that mean score of male students in the experimental group 61.78 while the mean score of the female students 58.90 with a calculated t value of 1.46 and significant $p>0.891$. Therefore the null hypothesis is retained. This implies that even with a mean gain difference of 2.89 between the male and the female students there is no significant difference in the scores of male and female exposed to the formative assessment strategy.

\subsection{Discussion of Findings}

Studying the effect of formative classroom assessment gives educators a better understanding of one process that appeared to have brought about genuine critical learning and has greatly impact students' academic achievement. The result of the study showed a significant differences in the formative classroom assessment between the experimental and the control group in favour of the experimental group. The result of the analysis showed that the students in the experimental group scored higher on the assessments which had strong effect on the academic performance of the junior secondary school two Basic Science students. This implies that students in the experimental group demonstrated a much deeper conceptual understanding of the topics in the unit and were better able to articulate their thinking in a concise manner compared to the control group. This indicate that formative classroom assessment strategy is effective in enhancing the students' academic performance. This finding supports Mawak and Ugodulunwa (2012) who found significant effect of formative feedback on SSII students' achievement in the experimental group than the control group in their study. Also the finding is in line with the result obtained by Ali and Igbal (2013) who observed that students' means achievement scores on a post-test of the experimental group was significantly better than that of the control group. However, this is not surprising because Ojugo (2013) has observed that formative assessment is useful to the students as it helps to diagnose students' learning difficulties and help them understand the difficulties of contents so as to improve their academic achievements in the subject.

The result of the study also revealed that formative assessment strategy is effective in improving the academic performance of the junior secondary school two Basic Science students as it was observed that a significant difference existed in the experimental group between the pre- test and the post -test scores and the difference is in favour of the post- test scores. This is an indication that the formative feedback promoted the junior secondary school two Basic Science students performance. This is not surprising as research evidence has shown that students who were provided with such feedback became more attentive and involved in the learning process and began to see the assessment process as a tool to help foster growth. Consequently, students tended to learn more and achieve at a higher level when they responded to assessment results by knowing where they were on the path to success, where they were headed, and what they needed to do to reach that accomplishment (Black, Harrison, Lee, Marshall, \& Wiliam, 2004; Ruland, 2011; Leahy, Lyon, Thompson \& Wiliam,, 2005). This finding also corroborates Tahir, Tariq, Mubashira and Rabbia (2012) whose study on impact of formative assessment on academic achievement of secondary school students reported that the posttest indicated a significance difference in the mean scores of both groups.

Lastly, the result of this study revealed that there was no significant sex difference in the effect of formative classroom assessment strategy on the academic achievement scores of junior secondary school two Basic Science students. In order words, the treatment had similar effect for both male and female students exposed to the formative classroom assessment. This implies that differences in performance between male and female students is not dependent on classroom formative assessment even though the result from the research showed relative difference in the mean scores of the male and female students. The female can even perform far better than male if the male students are not dedicated to their learning process. Thus the finding from this research agreed with Ajobgeje, (2013) and Olagunju (2015) who concluded that there is no gender difference in the achievement scores of Mathematics students that are exposed to formative assessment. 


\section{Conclusion}

Assessment is a major tool to consider in making educational decisions such as daily classroom decisions among others. If instructional decisions are to be made from classroom assessment them it is very important that such assessment be combined with teaching and learning process. The outcome of this study revealed that within the classroom, formative assessment is effective in improving the academic achievement of junior secondary school two Basic Science students as observed in the difference between experimental and the control group; pre-test and post-test; and also found to be effective irrespective of gender. In the view of this, the study concluded that when teachers are committed to using formative classroom assessment with timely feedback mechanism, students' academic performance will be positively impact.

\section{Recommendations}

In light of findings from this study, the following recommendations are made:

- Teaching and learning at the junior secondary school should be improved by regular formative classroom assessment with adequate feedback and remediation for learners to improve their academic achievement.

- The government and school administrators should allow and provide incentives for teachers to attend seminars, workshops, conferences and in-service trainings on how to blend formative assessment with classroom procedures.

\section{References}

Afemikhe, O. A. (2018). Big data in assessment for learning in the Nigerian education system. Paper to be presented at the IAEA conference held in Oxford September 9-12, 2018.

Ajogbeje, O.J. (2013). Effect of Formative Testing with Feedback on Students' Achievement in Junior Secondary School Mathematics in Ondo State Nigeria: International Journal of Education Research, 2, (2013).08-20.

Ajogbeje O.J. (2012). Path - Analytic Model and the Effect of Some Teaching Strategies of Variables Affecting Achievement in Junior Secondary School Mathematics in Ondo State. Unpublished Ph.D. Thesis, Ekiti State University, Ado-Ekiti, Nigeria.

Ali, I., \& Igbal, M.H. (2013). Effect of Formative Assessment on Students' Achievement in Science. World Applied Sciences Journal, 26(5), 677-687.

Association for Supervision and Curriculum Development (ASCD), (2016).Using assessment thoughtfully. 10 14.

Assessment Reform Group (2002). Assessment for Learning: 10 principles: researched based principles to guide classroom practice. Assessment reform Group. [Online] Available: http:/www.aaia.org.uk/content/uploads (June 11, 2010).

Black, P., Harrison, C., Lee, C., Marshall, B., \& Wiliam, D. (2004). Working inside the Black box: Assessment for learning in the classroom. Phi Delta Kappan, 86(1).

Federal Republic of Nigeria (2008). National Policy on Education. Yaba Lagos: NERDC Press.

Gronlund, N. E. (2006). Assessment of student achievement. ( $8^{\text {th }}$ ed). Boston: Allyn and Bacon.

Joshua, M.T. (2013). National Assessment of learning system and National Transformation. Nigerian Journal of Educational Research and Evaluation, 12(1), 1-17.

Leahy, S., Lyon, C., Thompson, M., \& Wiliam, D. (2005). Classroom assessment: Minute by minute, day by day. Educational Leadership, 63(3), 18-24.

McManus, S. (2008). Attributes of Effective Formative Assessments. In T. C. o. C. S. S.Officers (Ed.), Formative Assessment for Teachers and Students State Collaboration on Assessment and Student Standards of the Council of Chief State School Officers: The Council of Chief State School Officers. Pp 3

Marsh, C.J. (2007). A Critical Analysis of the Use of Formative Assessment in School. Education Research and Policy Practice, 6, 25-29.

Mawak, J. L., \& Ugodulunwa, T. (2012). Formative assessment and the improvement of middle school science learning: The role of teacher accuracy. CRESST Report 740: National Center for Research on Evaluation, Standards, and Student Testing (CRESST).

Nitko, A., \& Brookhart, S. (2007). Educational assessment of students. ( $5^{\text {th }}$ ed). Upper Saddle River, New Jersey: Pearson Inc.

Ojugo A.A. (2013). Effect of Formative Test and Attitudinal Types on Student's Achievement in Mathematics in Nigeria. African Educational Research Journal, 1 (2). 113-117.

Olagunju, A. M. (2015). The effect of formative assessment on Students' achievement in secondary school Mathematics. International Journal of Education and Research. 3 (10), 481-490

Ruland, J. W (2011). The Impact of Using Formative Assessment Attributes in Daily Instruction on Student Affect. A dissertation submitted to the faculty of the graduate School of Education in candidacy for the degree of Doctor of Education, Loyola University Chicago. [Online]. Available: http://ecommons.luc.edu/luc_diss/44 
(September 9, 2016).

Smith, L. (2008). Using formative assessment results to predict student achievement on high stakes tests. Unpublished Dissertation, Liberty University, Virginia.

Suliman, I. (1999). Assessing Student Learning. The University of New England.

Tahir, M., Tariq, H., Mubashira, K., \& Rabbia, A. (2012). Impact of Formative Assessment on Academic Achievement of Secondary School Students. International Journal of Business and Social Science, 3(17), 101-104.

Ugodulunwa, C. A., \& Uzoamaka, P. O. (2015). Effect of Formative Assessment on Mathematics Test Anxiety and Performance of Senior Secondary School Students in Jos, Nigeria: Journal of Research and Method in Education. 5 (2), 38-47.

William, D., Lee, C., Harrison, C., \& Black, P. (2014). Teachers developing assessment for learning: Impact on student achievement. Assessment in Education Principles Policy and Practice, 11(1), 49-65. 